\title{
Kvinders smag for mænd,
}

mænds smag for kvinder

\section{Heteroseksualitet som smagsfællesskab}

\section{Af Morten Emmerik Wøldike}

Heteronormativitet og bievarkiske dikotomier, som mand over kvinder, hetero over homo, normal over queer, $u$ dgør det sparsomme begrebsrepertoive $i$ de dominerende fortallinger om heteroseksualitet $i$ den danske køns- og seksualitetsforskning. Her udarbejdes en alternativ videnskabelig historie om heteroseksualitet som smagsfallesskab $i$ det senmoderne Danmark.

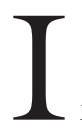

mange år fik vi bundet på ærmet, at heteroseksualitet var et uforanderligt naturfænomen, som alle skulle rette sig efter. Denne 'sandhed' er ikke længere helt så dybt forankret i os. Det skyldes ikke mindst en progressiv køns- og seksualitetsforskning, der længe har stillet kritiske spørgsmål til heteroseksualiteten. Men der er også sket en række samfundsmæssige forandringer, som jeg skal uddybe mere indgående, der $\mathrm{i}$ disse år ændrer de konkrete senmoderne, heteroseksuelle livsforhold: Det er bl.a. ikke mere helt så oplagt og nødvendigt at vare heteroseksuel; kvinder og mænd har mulighed for at blive noget andet, fortolke og fremføre deres køn, seksualitet og krop på en anderledes måde. At være heteroseksuel nærmer sig således lige som al anden og mindre udbredt seksuel og kønnet eksistens mod i højere grad at blive et personligt valg, en mulighed, et problem og en opgave, der kræver uafbrudt refleksivt arbejde af den enkelte.

Den brudvise løsrivelse fra normen om 
heteroseksualitet åbner ikke blot for, at den enkelte må føje nyt indhold og betydning til det at leve heteroseksuelt, men betyder også, at heteroseksualitet i dag - i lighed med homoseksualitet og andre seksualiteter - fremstår som et sociokulturelt fæenomen, der kalder på nye videnskabelige historier og fornyet opmærksomhed og interesse fra forskere og studerende. Udfordringen for nye seksualitetsfortællinger må være at bringe heteroseksualitetens afnaturalisering frugtbart videre og hjælpe de positive udviklingstendenser på vej ved at inddrage nye perspektiver: Om f.eks. også glæden og lysten ved at være heteroseksuel, om at nyde at være en kvinde, der har lyst til mænd og omvendt. Jeg skal i denne artikel præsentere et sådant alternativt perspektiv og kvalificere en ny videnskabelig historie, der betragter og begrebsliggør heteroseksualitet $\mathrm{i}$ det nuværende senmoderne Danmark som et som smagsfællesskab. I denne fortælling anlægges et æstetisk-livsorienteret perspektiv på seksualitet med vægt på kategorier og dimensioner som lyst, socialitet, sanselighed, følelser og identifikation. Inspirationen hentes fra uomgængelige $\mathrm{Mi}$ chel Foucault, den franske samtidsdiagnostiker Michel Maffesolis bejaende postmoderne socialitetsperspektiv og danske Henning Bechs kvalificerede sociologiske historier om byliv, seksualitet, køn og senmodernitet.

\section{KRITIK OG AFNATURALISERING AF HETEROSEKSUALITET}

Den videnskabelige verden domineredes i mange år af biologiske og medicinske seksualitetshistorier. Hovedlinjen i disse fortællinger var forestillingen om det heteroseksuelle kosmos: Det monogame forhold mellem mand og kvinde som eneste rigtige princip for organisering af menneskeligt samliv, lyst og følelser (Warner 1993, Katz 1990). Selv den tidlige feministiske teoridannelse og homoforskningen, der forsøgte at give mæle til kvinder og homoseksuelle, tog den heteroseksuelle norm for givet. Disse 'minoritetshistorier' forstærkede dermed blot de hierarkiske dikotomier mand/ kvinde og hetero/homo og kom i sidste ende snarere til at nære normen om heteroseksualitet end at dekonstruere den og eliminere dens dominans (Richardson 1996, Kitzinger \& Wilkinson 1993).

Foucault er en af kardinalfigurerne i en nyere bølge af historier, der beredte vejen for heteroseksualitetens afnaturalisering. I sit banebrydende værk Seksualitetens historie fra 1976 lancerede han en analyse af 'seksualiteten' som et moderne, socialt produceret fænomen: En installation ('dispositif') og erfaring ('experiénce') (Foucault 1978, 1985). I de næste årtier vandt denne socialkonstruktionistiske analysestrategi frem i bl.a. den gren af de feministiske videnskaber, som kaldes feministisk poststrukturalisme, der igen er tæe beslægtet - og på flere punkter overlapper - med en samling andre nyere seksualitetshistorier, som i de sidste to årtier har gået under betegnelsen queer theory. ${ }^{2}$ Fremtrædende eksponenter er f.eks. Michael Warner, Jonathan Katz og Judith Butler og i skandinavisk sammenhæng Don Kulick og Dag Heede.

Disse historier har over et bredt felt lige fra historiske og sociologiske til litterære og kunstkritiske studier og analyser bidraget frugtbart til at gøre heteroseksualitet tilgængelig for kritik. Til gengæld har de udpræget angelsaksiske historier vundet så stor udbredelse, at de - også i Danmark har opnået nærmest monopol på at udtale sig om heteroseksualitet og begrebsliggøre den med deres yndlingsbegreber, -perspektiver og -strategier om magt, diskurs, identitet, heteronormativitet, homofobi, performativitet og queering/mærkeliggørelse. For at illustrere nødvendigheden af at bryde dette monopol og kvalificere helt nye historier om heteroseksualitet drøftes i de følgende afsnit dels Butlers meget anerkendte teori, og dels nogle mere generelle træk ved queer theory - begrebet om heteronormativitet, forsøg på at overskride hierarkiske 
dikotomier og identitetsdannelser; konstruktive kritiske drøftelser, der tjener som afsæt for den efterfølgende præsentation og promovering af fortællingen om det senmoderne heteroseksuelle smagsfællesskab.

\section{HETEROSEKSUALITET - \\ ET MONOLITISK FÆNOMEN}

Diskurs er den helt primære kategori i Butlers diskurskonstruktionistiske teori; den er det i ekstrem grad, idet hun opløser alt i diskurser, hvormed magt blot er et resultat af den styrke, diskurserne får. Butlers ekstremitet viser sig også ved, at hun fører diskursteorien til sin grænse, hvor den må suppleres med andre begreber og historier - en "nødvendig, politisk fiktion" som hun kalder det (Butler 1993: 98, Meijer \& Prins 1998: 277). For Butler er sproget performativt, hvilket betyder, at en sproglig ytring også er en handling, der bringer det til verden, som den benævner. Diskurserne bliver magtfulde ved, at de gentages som sproglige citeringer og performative påbud om kønnet heteroseksualitet og forbud om homoseksualitet. Den heteroseksuelle diskurs ('matrix') gentages og citeres hele tiden $\mathrm{i}$ det sociale liv som henvisninger til diskursen, der igen henviser til diskursen og så fremdeles. Disse endeløse henvisninger skaber den heteroseksuelle matrix som en slags moderdiskurs, der virker tilbage og skaber nye henvisninger. I sig selv er den dog hverken en essens eller en original, men en henvisning på henvisning, et konglomerat af kopier, en fiktion. Butlers idé om seksualitetens (og kønnets) performative konstituering åbner forskellige muligheder og strategier for at destabilisere normen om, at mænd og kvinder påtager sig en identitet som heteroseksuel (Butler 1993, Stormhøj 2006: 81ff).

Der rejser sig imidlertid et interessant problem i Butlers teoriunivers, for hvad eller hvem føjer og modsætter sig diskurserne, hvis både kroppe og subjekter netop er resultat af disse normregulerende diskurser?
Med andre ord mangler der et led, hvormed diskurserne kan blive magtfulde. Der må således være en forudeksisteren, en prædiskursiv subjektstørrelse, som underkaster sig eller misbilliger diskurserne. Butler er opmærksom på problematikken og læser netop Foucault som eksponent for en sådan 'diskursiv monisme', der leder til den kortslutning, at diskurser konstruerer den sociale virkelighed og kønnede/seksuelle identiteter (Butler 1993: 97-8, 192). I stedet vender Butler blikket mod Jacques Lacan og importerer hans psykoanalytiske fortælling om eksistensen af en præmenneskelig kropsmasse, der udstyret med rørelser af frygt, begær og behov for identifikation kobler an til diskurserne og giver dem styrke. Disse bevægelser er meget forskellige, og den kraft, der ligger i begæret, er så stærk, at den ikke altid følger diskursen. Denne destabiliseringsfaktor forrykker mulighedsfeltet af identiteter, hvormed fremkomsten af 'forbudte' og 'uforståelige' identiteter, f.eks. den homoseksuelle, muliggøres (Butler 1993: 98ff).

Muligvis havner Butler ikke i en monistisk diskursbane, men heteroseksualitet kommer i hendes verden til at fremstå som et monolitisk fenomen: Heteroseksualitet begrebsliggøres og undersøges kun inden for en problematisk og negativ horisont; den står i et dybt strukturelt, hierarkisk dikotomiseret forhold til homoseksualitet, som en udelukkende ekskluderende norm, en påbudt adfærd og påtvunget identitet konstrueret af diskursive performativers sammenvoksning med ubevidste prædiskursive rørelser, der går forud for subjektiveringen. I denne endimensionale fortælling synes den heteroseksuelle (mennesket), som flere kritikere (f.eks. Jackson 1999: 180ff, 1996: 29, Prieur \& Moseng 2000: 145ff, Bech 2005: 65ff) også på forskellig vis har formuleret, forvandlet til et anæmisk og abstrakt væsen, og den levende krop og eksistens, som sanser, erfarer, reflekterer, føler, handler og føler lyst, ses der bort fra. Der er desuden heller ikke indbygget me- 
gen mulighed for ændringer og teoretisk at tænke forandringspotentialer i Butlers ufravigelige ramme: De hierarkiske dikotomier og normativ heteroseksualitet virker meget uforanderlige og noget stereotype, når man holder dem op mod senmoderne danske køns- og seksualitetsforhold.

Set i et historisk perspektiv har det været berettiget at sætte kritisk fokus på de negative effekter af heteroseksualitet og anskue den fra de marginaliserede, ekskluderede minoriteters synsvinkel: Kvinders, homoseksuelles, transseksuelles, queers side. De toneangivende køns- og seksualitetsfortællinger i dag, som f.eks. Butlers, synes dog noget ureflekteret at fortsætte med udelukkende at betragte og analysere heteroseksualitet fra denne synsvinkel ved på forhånd at udpege heteroseksualitet/den normative heteroseksualitet som 'skurken' eller 'det onde', der skal bekæmpes og forandres. Ligeledes er det typisk også i teoretiske og empiriske undersøgelser af andre sociokulturelle fænomener, som f.eks. homoseksualitet, etnicitet, køn, maskulinitet, seksualisering og pornografi, at der sideløbende og sekundært udfoldes, hvad heteroseksualitet kunne tænkes at være for et fænomen. ${ }^{3}$ I den fremherskende køns- og seksualitetsforskning i dag er det i høj grad heteroseksualiteten, der er minoriteten, og de heteroseksuelle stemmer lyttes der slet ikke til!

\section{HETERONORMATIVITET, NYE HIERARKISKE DIKOTOMIER, NYE IDENTITETER}

(Hetero)normativitet er hovedkategorien i queer theory, der voksede frem i USA inspireret af den aktivisme og bevægelse, der samlede sig om identitetskategorien queer i løbet af 1980'erne, hvor sygdommen aids brød ud og bl.a. forstærkede homofobien i USA. Queer-perspektivet adskiller sig fra homoforskningen og bøsse/lesbisk historie ved at skifte fokus fra det homoseksuelle subjekt til heteroseksualiteten som genstandsfelt for kritisk analyse, fordi den vir- ker som et socialt og politisk organiserende princip for samfundet - et normaliseringsregime (Warner 1993: xxviff, Kulick 1996: 6-7).

I sit udgangspunkt er queer theory tænkt som et opgør med de hierarkiske dikotomier mellem hetero/homo/bi/trans/interseksuelle og ikke mindst de identiteter, som de udstikker. Disse prægede de tidligere seksualitetshistorier, gravede ganske ufrugtbart grøfter mellem heteroseksuelle/majoriteten og homoseksuelle/minoriteten og resulterede i eksklusion og undertrykkelse på baggrund af køn og seksualitet. Inklusion er derfor en yderst vigtig strategi i queer-perspektivet. Forestillingen er, at queer kan forene alle mennesker, der tager afstand fra heteronormativitetens herredømme, i et fælles politisk projekt. Det gælder uanset deres køn, seksualitet, og hvilke varianter af lystfølelser og kropsudfoldelser de iscenesætter - lige fra 'hvide heteroseksuelle mænd', transseksuelle, masochister til 'sexsælgere' og 'sexkøbere' (Warner 1993: xxiff, Kulick 2007).

Ideerne om inklusion og et ikke-moralistisk syn på seksualitet er positive træk, men det svage punkt er derimod, at queer-perspektivet helt på linje med de gamle seksualitetshistorier antænder en ny binær oppositionsdannelse mellem queer og straight/ normal. Tanken om queer som en flydende, diffus og udefineret antiidentitet, der inkluderer og ikke udelukker, spinder homoseksuelle, biseksuelle, transseksuelle, queers og alle andre, der regner sig under dette perspektiv, ind i et dualistisk magtforhold til det normale, heteronormativiteten eller i værste fald de heteroseksuelle. Det, der var tænkt som en antiidentitet, bliver således til identitetskategorien queer. Perspektivet leverer en slags udvidet minoritetsfortælling og begår et selvmål ved, at den - trods sin hensigt om det modsatte - forbliver i en ramme, hvor tænkningen i identitet fastholdes, og de hierarkiske dikotomier fortløbende reproduceres. ${ }^{4}$ 


\section{NYT PERSPEKTIV PÅ}

\section{HETEROSEKSUALITET}

De kritiske drøftelser ovenfor viser, at Butler og queer theory tilbyder nogle temmelig snævre og ensidige teoretiske og begrebsmæssige perspektiver på heteroseksualitet ved udelukkende at belyse den gennem et magt- og undertrykkelsesperspektiv. Det gør dem blinde og ikke-sensitive over for andre dimensioner, hvilket alene er begrundelse nok for at kaste lys over andre perspektiver og supplere med nye historier om heteroseksualitet - i respekt for at det er et komplekst og mangeartet fænomen, der naturligvis må undersøges flerdimensionalt. Når man retter blikket stift mod magt, hierarki, dikotomi og normativitet, er der ligeledes også stor risiko for, at man ikke ser andet og slet ikke andre forhold eller samfundsmæssige udviklinger, der måske er ved at udligne og muligvis forandre de tidligere modsætninger og magtforhold. Så vidt jeg kan se, er det netop stereotype hierarkiske dikotomier mellem mand/kvinde, hetero/homo, queer/normal, en dybt forankret og uforanderlig heteronormativitet samt en fortsat tænkning inden for en identitetshorisont, der stedse bliver bekræftet og reproduceret hos Butler og queer theory.

Spørgsmålet er således, om Butler og queer theory stadig leverer de mest passende og frugtbare perspektiver og historier om heteroseksualitet $\mathrm{i}$ en senmoderne dansk kontekst? De er givetvis passende og frugtbare i den angelsaksiske samfundskontekst, de udspringer af, men både sociale, kulturelle og økonomiske forskelle mellem USA og Danmark gør det problematisk at importere queer-perspektivet ukritisk til danske himmelstrøg. Vel er heteronormativiteten heller ikke helt ryddet af vejen i Danmark, men den gennemsyrer langt fra det nuværende samfund i en sådan grad, at den bør være det eneste og vigtigste perspektiv på heteroseksualitet.

Når disse historier ikke længere nødvendigvis er i overensstemmelse med udviklingen i det senmoderne Danmark, der også er præget af mangfoldighed og pluralisme, hvad angår køn, seksualitet, parforhold og leveformer, er de måske heller ikke mere de strategisk set mest frugtbare historier at cirkulere, hvis vi reelt ønsker at fjerne modsætninger og fremme demokratisk samliv. Ligesom forskere forsøger at indfange og forklare de forhold, der er på spil i samfundet, siver de historier, der produceres i akademia, også ud i samfundet og får indflydelse på de fortællinger og sandheder, samfundet producerer om sig selv.

Queer theory og feministisk poststrukturalisme åbner således for at tænke ud over de hegemoniske seksualitetshistorier og dermed række ud efter helt nye historier, der løsner seksualitets- og selvinstallationerne, udvider mulighedsrummet og minimerer eksklusionen. Foucault havde faktisk blik for, at (hetero)seksualitet er et komplekst og flersidet fænomen, der må undersøges som mere end blot en diskurs eller institution, norm og identitet. Med sit dobbelte analysegreb om 'seksualiteten', der på den ene side - udefra set - er en installation af diskurser, institutioner, praktikker og teknikker drevet frem af magten, og på den anden side - indefra set - er menneskers erfaring og oplevelse af seksualiteten, nedtoner den sene Foucault diskursernes forrang (Foucault 1977: 197, 1985: 4ff, Dreyfus \& Rabinow 1982: 176, Jackson 1996: 29ff, 2003: 72). En sådan socialkonstruktionistisk og fænomenologisk undersøgelse af heteroseksualitet som historiske former for erfaring og levevis, en livsform med dertil knyttede livsbetingelser og muligheder for socialitet, baner vej for en bredere analysetilgang til heteroseksualitet, der også ser mere bejaende på, hvad det vil sige at være heteroseksuel.

FRA MAGT OG IDENTITET

TIL ÆSTETISK SOCIALITET OG

SMAGSSTAMMER

En sådan teoretisk tilgang til seksualitet kan finde inspiration hos den franske sociolog 
Maffesoli, ${ }^{5}$ der vender sig mod den traditionelle tænkning i sociologien, hvor enten individet eller samfundet gøres til primær kategori. Det har fremmet dikotomien mellem den individuelle og den sociale verden og ydet sit til, at identitetsbegrebet er blevet den mest centrale figur i moderne samfundstænkning. Maffesoli skelner mellem den moderne og den postmoderne epoke, der træder frem i dag: Det er en verden vendt mod sig selv - uden guder og de store moderne sociale maskinerier, ideologier og fortællinger at fæstne lid til. At det sociale liv vendes mod sig selv betyder, at det farr værdi i sig selv. Det, der forbinder mennesker med hinanden, kommer i centrum som en piblende kreativitet og kollektiv kraft ('puissance') til at udtrykke forskellige erfaringer, der er konstituerende for fælles værdier og samvær (Maffesoli 1991: 8-15, 1990: 90).

Socialiteten er den kraft, der ifølge Maffesoli træder tydeligst frem i postmoderniteten. Den var tidligere pakket ind i religionens verden og modernitetens institutioner, men nu hvor disse har mistet slagkraft, viser den sig som det, den virkelig er: Det bærende grundlag for alt i livet. Forestillingen er, at der i menneskelivet er en driftsbåret søgen og lyst efter at etablere falles $f ø$ lelser med andre mennesker. De fælles følelser virkeliggøres ved, at de tager en form og finder et udtryk, som igen stimulerer ny trang til fælles følelser. Denne kontinuerlige knopskydning af estetiske udtryk og former binder mennesker sammen på baggrund af behov for samføling, fælles følelser og stemninger. Socialiteten er således æstetisk i den postmoderne tid, fordi den skaber følelser og udtrykker en form. Kroppen gestaltes f.eks. som noget, der skal ses på af andre; forskellige udsmykninger og iscenesættelser danner fællesskab, såsom piercing, tatovering, bodybuilding og fitness (Maffesoli 1996: 3ff).

Disse nye fællesskabsformer diagnosticerer Maffesoli som (masse)stammer ('neotribes', 'affectual tribes'), der vokser ud af massen af endnu større koncentrationer af mennesker. De er flygtige og midlertidige samlinger af mennesker, som netop er fælles om at dyrke bestemte udtryk, særlige former eller en specifik smag. Smagsstammerne adskiller sig således fra de moderne stabile socialitetsformer, hvor individet rationelt tilsluttede sig et socialt bånd, f.eks. en socialklasse, ud fra en fælles forståelse, socioøkonomisk baggrund, formulering af interesser, holdninger og sproglig kommunikation. En vigtig pointe hos Maffesoli er, at han netop ikke ser individualismen og narcissismen funderet $\mathrm{i}$ individet, men i kollektivet: Det er lysten til at være sammen med andre, der får dem til at stimle sammen for at dyrke, producere og leve en speciel livsstil, f.eks. tøjsmag og sportsform eller særlige seksuelle nydelsesformer (Maffesoli 1996, 1991).

Maffesolis postmoderne optik fører ligeledes til et opgør med den udbredte opfattelse af mennesker som individer, der er udstyret med en fast identitet skabt på baggrund af tilhørsforhold til eller funktion i en specifik gruppe. I steder anvender Maffesoli begrebet persona som betegnelse for 'den', der spiller forskellige roller med de masker og kostumer, der giver adgang til de smagsstammers scener, som man tiltrækkes af. Det at kunne genkende sig selv i det kollektive kommer derved helt i front, hvormed et begreb som identifikation frem for identitet - bedre kan indfange den omskiftelighed, foranderlighed og bevegelse, som kendetegner menneskers liv i den nuværende pluralistiske og polyvalente tid (Maffesoli 1996: 76-7, 91).

\section{HeTEROSEKSUALITET SOM \\ SMAGSFÆLLESSKAB}

Anlægger man Maffesolis æstetiske socialitetsperspektiv og anskuer heteroseksualitet som et smagsfællesskab, bringer man sig reelt ud over at betragte heteroseksualitet som en tvingende norm, konstitueret hierarkisk og dikotomisk $\mathrm{i}$ forhold til andre 
seksualiteter, samt at betragte heteroseksuelle som en masse, der udgør en identitetsbevægelse. Det heteroseksuelle smagsfællesskab er derimod et løst og flygtigt, emotionelt stemningsbåret og rumligt situeret fællesskab. Her opdyrker kvinder og mænd deres lyst til at være sammen med det modsatte køn, nyder hinandens kroppe og deler glæden ved nogle fælles symboler, tegn og ritualers æstetik, der ikke har anden mening og formål, end at de har lyst til at være sammen.

Fortællingen om heteroseksualitet som smagsfællesskab fokuserer på heteroseksuel lyst, de rstetiske kvaliteter ved denne præference, og den fænomenologiske kategori smag - i en 'ren' og 'subjektiv' forståelse og ikke som markør for distinktion, kapital og magtposition, som f.eks. i Pierre Bourdieus relationelle og antisubstantialistiske sociologi - erstatter identitetsfiguren som betegnelse for den heteroseksuelle præference. Frugtbarheden ved at karakterisere seksuel lyst og følelser rettet mod det modsatte køn som udtryk for en bestemt smag er, at man kommer ud over modsætninger og identitet, fordi smag pr. definition er forskellig og varierer fra person til person. Man er ikke født med en smag, derfor kan den ændre sig og nye smagsorienteringer kan opstå (Bech 1997: 208ff, Lützen 1998: 171).

En række samfundsmæssige forandringer i heteroseksuelles leveformer og livsbetingelser i det senmoderne Danmark understreger også det passende i at begrebsliggøre den heteroseksuelle præference som smag. Mange af de livsbetingelser, som før var kendetegnende for homoseksuelle, er i dag blevet alment udbredte: Heteroseksuelle oplever således ikke nødvendigvis mere familien og xgteskabet som eneste måde at organisere livet på; mange kvinder og mænd lever 'uden' for kernefamilien, bliver skilt, er serielle monogame, etablerer korte og mange seksuelle møder, færdes i æsteticerede og seksualiserede byrum, dyrker også oralsex og analsex (jf. Bech 2005) eller nyder pornografi med analsex, gruppesex eller 'gangbang', hvor deres eget køn er i centrum (jf. Hald 2007: 55). De accepterer et bredt udsnit af forskellige seksuelle krops- og livsudfoldelser (f.eks. Bondeson 2003). Dertil kommer, at de sociale kønsforskelle mellem kvinder og mænd på flere områder ikke længere er så fremtrædende i Danmark. En lignende udvikling skitserer også den britiske sociolog Giddens, der ligeledes tager udgangspunkt i homoseksuelle som en slags pionerer for fremkomsten af to særlige seksualitets- og samværsformer, der er blevet almene i vestlige senmoderne kulturer: Dels en plastisk seksualitet, hvor kvinder og mænd hovedsageligt dyrker sex for orgasmens - og ikke reproduktionens skyld, og dels rene forhold, hvor de etablerer parforhold, der kun består, så længe begge parter făr noget ud af det følelsesmæssigt og seksuelt (Giddens 1994).

Disse forskellige forandringstendenser peger mod, at de hetero- og homoseksuelle leveformer konvergerer, som Bech har fremført i sin historie om den moderne homoseksuelle eksistensforms forsvinden i det senmoderne Danmark (især Bech 1997). Implikationen af denne historie er, at den heteroseksuelle eksistensform ligeledes tenderer mod at forsvinde. Når de homo- og heteroseksuelle således tilegner sig hinandens vilkår, leveformer og muligheder, er selve præferencerne den tilbageværende forskel, der ikke bare, som Bech foreslår, kan forstås som en smag for homoseksuelles vedkommende, men ligeledes at heteroseksuelle kvinders og mænds seksuelle præference kan begribes som en smag. Det heteroseksuelle smagsfællesskab samler pt. flest mennesker i Danmark, men da heterosocialitet og -sex har mange forskellige ansigter og udtryk, må man forestille sig hetero-stammen udspaltet i myriader af mindre fællesskaber, hvor særlige lyster, livsformer, opleve- og socialitetsformer dyrkes, som det f.eks. ses i swinger- og sex-klubber, SM-miljøer, fitnesscentre, diskoteks- og musikklubarenaer, ved fetichfester og inter- 
netfællesskaber som Scor.dk, Dating.dk, Elitedating.dk, Facebook.com, etc.

\section{ETIK I SEKSUELLE SMAGSFÆLLESSKABER}

Hvor der er smag, vil der også potentielt være afsmag, og hvad der bejaes og fejres $i$ ét smagsfællesskab, kan være betydningsløst og udtryk for dårlig smag i andre. Enhver smagsorientering søger naturligvis at brede sig, hvilket ikke helt kan udelukke konflikter og spændinger mellem forskellige fællesskaber. Afgørende er dog, at smagsfællesskaberne helt grundlæggende slet ikke er drevet af modsætninger, kamp, rivalisering, hierarki og dikotomi. Mennesker søger netop ind i smagsfrellesskabet for at nyde samværet med andre og varmen ved nærværet fra andre. Det seksuelle smagsfællesskab udstråler således også en estetisk etik; den form eller det udtryk, som mennesker stimler sammen omkring, baserer sig på fælles følelser og stemninger, der for den enkelte person får karakter af en simpel etik, en etisk erfaring ('ethical experience') (Maffesoli 1991: 17, 1996: 16-20).

Men hvilke etiske potentialer har det seksuelle smagsfællesskab egentlig? For det første er smagsfællesskabet hverken bindende eller forpligtende: Man kan til enhver tid droppe ud, hvis man mister appetitten eller får lyst til noget andet. Der følger heller ingen sanktioner i kølvandet: Man holder bare op med at dyrke sex med personer af eget køn, hvis man vil forlade homostammen. Den flydende, omskiftelige og uforpligtende karakter tilfører omvendt smagsfællesskabet en potentiel overfladiskhed og tragisk kunstighed: Der gives ingen løfter om vedvarende samvær og solidaritet (Maffesoli 1991: 16, 1996: 76ff). For det andet slår Maffesoli til lyd for, at spændinger og modsætninger mellem seksuelle smagsorienteringer kommer til udtryk gennem mere ligeværdig leg og spil, f.eks. med seksuelle ritualer og kropslige iscenesættelser, der ikke medfører kamp, strid, eksklusion og lemlæstelse (Maffesoli 1989: 2ff, 1996: 76).
For det tredje fremhæver Maffesoli, at såvel som enhver historisk periode er præget af særlige ideer og ideologier, kendetegnes den også ved en særlig grundstemning ('ambience', 'atmosphere'). I det moderne var det rationalismen og individualismen, men i postmoderne tid opstår en særlig følelseskultur og -stemning ('emotional atmosphere') som en grundramme, alle mennesker handler og orienterer - og altså samler sig i frellesskaber - efter (Maffesoli 1996).

\section{AFSLUTNING: \\ ULTIMATIV AFNATURALISERING AF HETEROSEKSUALITET}

De for tiden toneangivende videnskabelige historier inden for køns- og seksualitetsforskningen, her eksemplificeret med Butler og queer theory, har bidraget til afnaturaliseringen af heteroseksualitet og sidestillet den med andre seksuelle eksistensformer. Disse historier anlægger dog et ovenud negativt og monolitisk syn på heteroseksualitet og evner ikke at pege ud over hierarkiske dikotomier om mænd/kvinder og heteroseksuelle/homoseksuelle, de normative sider af heteroseksualiteten og den logik, der ligger i en identitetstænkning. Resultatet er en stædig, ufravigelig holden fast i disse perspektiver og sandheder om heteroseksualitet i det senmoderne Danmark. De sprækker af forandringer i det senmoderne Danmark, der peger væk fra den obligatoriske heteroseksualitet, dvs. mere frihed til at vælge og gøre sit køn og seksualitet samt større mangfoldighed i leveformerne, aktualiserer behovet for at bryde de fremherskende historiers monopol og supplere dem med et anderledes og mere positivt blik på heteroseksualitet. Et blik, der forsøger at indfange de erfaringer, oplevelser og socialitetsformer, som kendetegner heteroseksuelles liv i dag - og som ikke forfalder til at reducere heteroseksualitet til en i bedste fald 'undertrykkende norm', som Butler og queer theory gør, eller i værste fald heteroseksuelle som 'undertrykkere' ${ }^{6}$ 
Fortællingen om den heteroseksuelle eksistensforms forsvinden og heteroseksualitet som smagsfællesskab er et anderledes perspektiv, der bryder afgørende med de gængse historier om heteroseksualitet. I modsætning til sociale identitetsbevægelser binder smagsfællesskabet og den xstetiske socialitet ikke mennesker til en identitetskategori, men er løsere og uforpligtende, og smag er i modsætning til identitet mere demokratisk, mindre tvingende og foranderlig qua sin kobling til lysten, sanserne og følelser. Det synes også at harmonere med, at færre i Danmark efterhånden kommer i klemme, hvis de skifter seksuel smag undervejs i livet, eller hvis de som helt unge udvikler smag for det samme køn, hvilket adskiller dem fra den præference, de fleste af deres venner flokkes om.

Heteroseksualitet som smagsfællesskab peger ikke kun frem mod den ultimative afnaturalisering af heteroseksualitet, men har også et grundsociologisk ærinde om at berede vejen for mere lighed og bedre vilkår for mennesker i samfundet. Et farvel til den moderne heteroseksuelle eksistensform er et lykkeligt endeligt, der peger på en ultimativ ligestilling mellem seksuelle lystformer. Ikke kun til gavn for os, der dyrker andre lyst- og samværsformer, men også for heteroseksuelle selv. Den kan løsne dem fra seksualitetsinstallationens åg og en eksistensform styret af normer, vaner og forhåndsfastlagte livsbaner; den kan frisætte dem til at dyrke og fejre deres præference uden dårlig samvittighed - afsøge verden for andre lyster og følelser, finde nye rum og muligheder for heterosocialitet og -sex. En sådan bevidstgørelse vil også kunne revitalisere heteroseksualiteten som lystform, medvirke til at genfortrylle den og binde mænd og kvinder sammen på nye og hidtil usete måder.

Begrebsliggørelsen af heteroseksualitet som smagsfællesskab har også frugtbare perspektiver i forhold til aktuelle politiske problemstillinger i Danmark. Ved at statuere den heteroseksuelle præference som en smag, bortfalder argumentet om, at heteroseksuelle a priori (dvs. med henvisning til 'natur', biologi, etc.) har flere rettigheder end f.eks. homoseksuelle, når det gælder retten til at blive forældre, adoptere børn, få foretaget insemination, få hjælp fra det offentlige, osv. Der er ikke så meget at diskutere: Én smag er ikke bedre eller mere rigtig end en anden. Seksualitetens forskydning fra politikkens og magtens felt - og biologien generelt - til et fænomen, der også må begribes sanseligt-æstetisk, adskiller den helt fra problematikken om reproduktion, børn og familie, hvor heteronormative synspunkter stadig fra tid til anden dukker op (f.eks. Nørgaard \& Damgaard 2005, Grünbaum 2003, Malacinski 2008). Ved at betragte heteroseksualitet som smagsfællesskab fremhæves ligeledes kvinders og mænds lyst og socialitet til og med hinanden som et åbenlyst og grundlæggende positivt træk ved at være heteroseksuel, som går imod den udbredte fortælling om hierarkiske dikotomier og polarisering af kvinder som partout 'ofre' og 'undertrykte' af mænd og deres mistænkelige og dominerende seksualitet. En fortælling, der har fået vind i sejlene - ikke bare i mere 'højrereligiøse' kredse, men i foruroligende grad også i nogle feministiske og politiske kredse, især på 'centrumvenstre-fløjen'. Det har i de seneste år kunnet aflæses i stigende moralske bekymringer om forskellige mere eller mindre almindelige seksuelle nydelsesformer som oralsex, analsex, gruppesex, om pornografi og prostitution; og en seksuel moralisme, der i sidste ende rammer kvinder på deres seksuelle frihed ved at diktere dem, hvad de må og kunne have lyst til at bruge deres kroppe til i seksuelle henseender, f.eks. at nyde pornografi, adskille sex og kærlighed, seksualisere sig, sælge sex, give blowjobs, dyrke analsex og gruppesex, dominere og penetrere mænd, lade sig dominere af mænd, være sammen med flere mænd på en gang, osv. (Wøldike 2008).

Selv om der her er fremført kritik af feministisk poststrukturalisme og queer theo- 
$r y$, er hensigten ikke at detronisere disse fremherskende fortællinger. Heteroseksualitet som smagsfællesskab er en alternativ historie, som både synes passende i forhold til de foreliggende omstændigheder og mindst lige så - måske endda mere - frugtbar for ændringer til det bedre end bidragene fra Butler og queer theory. Der er dog styrker og svagheder ved begge historier, og de bør snarere supplere hinanden i konkrete analyser. Lad det være en opfordring til forskere og studerende om at kaste et mere nuanceret kritisk og flerdimensionalt blik på heteroseksualitet!

\section{Noter}

1. Jeg baserer artiklen på min eksamensopgave Nye historier om heteroseksualitet, indleveret på Sociologisk Institut, Københavns Universitet, januar

2002.

2. Benævnelsen queer theory er egentlig misvisende, fordi den ikke udgør en samlet teori. Queer theory - eller mere korrekt måske queer studies - er snarere et konglomerat af forskellige perspektiver og metoder, der som fælles mål bringer ny indsigt frem om identitet, kultur og samfund.

3. Et illustrativt - om end overfladisk - eksempel på min pointe får man ved et kig på KVINFO's bibliotek, hvor der slet ikke findes et emneindeks for heteroseksualitet. De få bøger, der specifikt handler om heteroseksualitet, må man derimod søge under temaer som 'seksualitet', 'homoseksualitet' og 'kønsfilosofi' (se www.kvinfo.dk under 'klassifikationer og emnegrupper').

4. Enhedslistens queerudvalg, der er en af de få kredse i Danmark, som har omfavnet queer-perspektivet, synes også at have problemer med helt at bryde med heteronormativiteten og leve op til ideen om et ikke-moralistisk syn på sex, der inkluderer forskellige seksualiteter og kropsudfoldelser, f.eks. også kvinder der sælger sex, 'prostituerede', 'sexarbejdere' eller (mandlige) sexkøbere. I et indlæg (Kabell, Hansen, Højlt \& Mertz 2002), der er offentliggjort på udvalgets hjemmeside, synes bekymringer og frygt for prostitution (der af mange ofte sættes helt lig med handel med kvinder og kvindeundertrykkelse) at skabe grænser for, hvem der kan inkluderes i queer, og hvilke områder af heteronormativiteten, der skal rettes kritik af. Men dermed er der ikke længere tale om queer-kritik, men snarere om klassisk feministisk moralisme, som gør prostitution til noget suspekt, ekskluderer prostituerede og deres kunder og bekræfter heteronormativiteten ved at artikulere en moralistisk opfattelse af, hvad kvinder må bruge deres krop til i seksuelt henseende. Moderpartiet Enhedslisten har ligeledes på sit årsmøde i 2007 besluttet - lige som SF - at arbejde for en kriminalisering af købesex i Danmark (Enhedslisten vedtager kriminalisering af prostitutionskunder, pressemeddelelse, www.enhedslisten.dk).

5. Der findes andre eksempler på anvendelser af Maffesoli i køns- og seksualitetsstudier, fx Bech 1999, Demant \& Klinge-Christensen 2004, Alzaga 2004 og Langdridge 2006.

6. I Danmark findes nogle fă artikulerede eksempler på 'hetero-fobi' - offentlige ytringer af had mod heteroseksuelle som f.eks. ved Copenhagen Pride i august 2005, hvor en unavngiven aktivistisk gruppe i homomiljøet opsatte plakater i byens gader bl.a. med ordlyden "Bekæmp hate crimes bank en heteroseksuel" (Vangkilde 2005).

\section{LITTERATUR}

- Alzaga, Cristina (2004): Pige på lagnet-socialitet, entreprenorvirksombed og risikovillighed $i$ indendorsprostitution. Kandidatafhandling ved Sociologisk Institut, Københavns Universitet, København.

- Bech, Henning (1997): When Men Meet-Homosexuality and Modernity. Polity Press, Cambridge

\& University of Chicago Press, Chicago.

- Bech, Henning (1999): After the Closet, i Sexualities $1999 / 2(3)$.

- Bech, Henning (2005): Kvinder og mand. Hans Reitzels Forlag, København.

- Bondeson, Ulla (2003): Nordic Moral Climate. Value Continuities and Discontinuities in Denmark, Finland, Norway, and Sweden. Transaction Publishers, New Brunswick/London.

- Butler, Judith (1993): Bodies that Matter. Routledge, New York.

- Demant, Jakob \& Klinge-Christensen, Charlotte (2004): Boybands \& teenagepiger - kønsidentitet og drømmen om romantisk karlighed. Forlaget Samfundslitteratur, København.

- Dreyfus, Hubert \& Rabinow, Paul (1982): Michel Foucault: Beyond Structuralism and Hermeneutics. The University of Chicago Press, Chicago. 
- Foucault, Michel (1977): The Confession of the Flesh, i Foucault, Michel: Power/Knowledge. Harvester Press, Brighton.

- Foucault, Michel (1978 [1976]): Seksualitetens historie 1: Viljen til viden. Rhodos, København. - Foucault, Michel (1985 [1984]): The Use of Pleasure. The History of Sexuality. Volume 2. Penguin Books, London.

- Giddens, Anthony (1994 [1992]): Intimitetens forandring. Seksualitet, karlighed og erotik $i$ det moderne samfund. Hans Reitzels Forlag, København.

. Grünbaum, Ole (2003): Ingen vil snydes. Berlingske Tidende 30/8/2003.

- Hald, Gert Martin (2007): Pornography Consumption: A Study of Prevalence Rates, Consumptions Patterns, and Effects. Psykologisk Institut, Aarhus Universitet, Århus.

- Heede, Dag (2003): En mærkelig indføring "It's still the same old story...", i Synsvinkler. Tidsskrift for nordisk litteratur og sprog. Queer Sernummer. Center for Nordiske Studier, Syddansk Universitet, Odense.

- Heede, Dag (2005): Hjertebrødre. Krigen om H.C. Andersens seksualitet. Syddansk Universitetsforlag, Odense.

- Jackson, Stevi (1996): Heterosexuality and feminist theory, i Richardson, Diane (ed.): Theorising Heterosexuality. Telling it straight. Open University Press, Buckingham.

- Jackson, Stevi (1999): Heterosexuality in Question. Sage, London.

- Jackson, Stevi (2003): Heterosexuality, Heteronormativity and Gender Hierarchy: Some Reflections on Recent Debates, i Weeks, Jeffrey, Holland, Janet and Waites, Matthew (eds.): Sexualities and Society. A reader. Polity Press, Cambridge. - Kabell, Morten, Hansen, Rasmus Præstmann, Højlt, Thomas \& Mertz, Liv (2002): Købesex 2. lokaliseret d. 1/9-2007 på www.queer.dk.

- Katz, Jonathan (1990): The Invention of Heterosexuality, i Socialist Review 1990/(6).

- Kitzinger, Celia \& Wilkinson, Sue (1993): Theorizing Heterosexuality, i Kitzinger, Celia \& Wilkinson, Sue (eds.): Heterosexuality. A Feminism os Psychology Reader. Sage, London.

- Kulick, Don (1996): Queer Theory: Vad är det och vad är det bra för?, i Lambda Nordica 1996/(3-4).

- Kulick, Don (2007): Skabelsen af en ny slags syg person: Sexkøberen, i Dansk Sociologi.

2007/l(18).

- Langdridge, Darren (2006): The time of the sadomasochist. Hunting with(in) the 'tribus', i Seidman, Steven, Fischer, Nancy \& Meeks, Chet (eds.): Handbook of the New Sexuality Studies.

Routledge, London.

- Lützen, Karin (1998): Social konstruktion af homoseksualitet, i Järvinen, Margaretha og Bertilsson, Margareta (red.) Socialkonstruktivisme. Bidrag til en kritisk diskussion. Hans Reitzels Forlag, København.

- Maffesoli, Michel (1989): The Sociology of Everyday Life, i Current Sociology 1989/37(1).

- Maffesoli, Michel (1990): Post-Modern Sociality, i Telos 1990/85.

- Maffesoli, Michel (1991): The Ethics of Aesthetics, i Theory, Culture \& Society 1991/8(1).

- Maffesoli, Michel (1996 [1988]): The Time of the Tribes: The Decline of Individualism in Mass Society. Sage, London.

- Malacinski, Leny (2008): Pia Kjærsgaard angriber homoer. Nybedsavisen, 9/2/2008.

- Meijer, Irene Costera \& Prins, Baukje (1998): How bodies come to matter: An interview with Judith Butler, i Signs 1998/23(2).

- Nørgaard, Lone \& Damgaard, Kirsten (2005):

Homoseksuelt forældreskab? Politiken

23/9/2005.

- Prieur, Annick \& Moseng, Bera Ulstein (2000):

'Sorry, we don't speak Queer' En kritisk kommentar til Queer teori.”, i Kvinneforskning 2000/3/4.

- Richardson, Diane (1996): Heterosexuality and social theory, i Richardson, Diane (ed.): Theorising Heterosexuality. Telling it straight. Open University Press, Buckingham.

- Stormhøj, Christel (2006): Poststrukturalismer. Videnskabsteori, analysestrategi, kritik. Forlaget Samfundslitteratur, København.

- Vangkilde, Jesper (2005): Hadekampagne mod homoparade. Urban 12/8/2005.

- Warner, Michael (1993): Introduction, i Warner, Michael (ed.): Fear of a Queer Planet. Queer Politics and Social Theory. University of Minnesota Press, Minneopolis

- Wøldike, Morten Emmerik (2008): Kandidatafhandling under udarbejdelse.

\section{SUMMARY}

Heterosexuality has been largely untheorised within both sociology, feminism and gay and lesbian studies, which have traditionally been focusing on hierarchical dichotomies between men and women, heterosexuality and homosexuality. As the most prominent tales of hete- 
rosexuality today, post-structuralism and queer theory have contributed fruitfully to the denaturalisation of heterosexuality, but have also gained a monopoly of telling stories which are neither necessarily productive in terms of the scientific integrity nor no longer helpful for people in general. The article puts forward a critique of these scientific tales, among others the work of Judith Butler, as contributing to a rather monolithic conceptualisation focusing on heterosexuality as only a 'discourse', an 'institution', an 'identity' or a 'norm'. Moreover, by constructing a new binary between 'queer' and 'normal', queer theory fails to transgress the logics and concepts of dichotomies and identity. The article argues that people in late modern Denmark in fact no longer strictly conforms to a hete- rosexual norm and therefore, it alternatively suggests a tale of heterosexuality as 'a tribe or community of taste' inspired by the sociologists Michel Maffesoli and Henning Bech, addressing perspectives and categories such as lust, taste, aesthetics, sociality, sensation and emotions. This new tale is not intended to replace post-structuralism or queer theory, but as both an adequate and a very productive qualified tale, it should be supplementary in respect of the fact that heterosexuality is a multifarious phenomenon which must be studied from various angles in different contexts.

Morten Emmerik Wøldike bac.scient.soc. og specialestuderende Sociologisk Institut, Københavns Universitet 